\title{
Managing Complexity and Resource-Based Strategy Cases in the Implementation of Food Security Policy in Indonesia
}

\author{
Novayanti Sopia Rukmana S ${ }^{1}$, Alwi ${ }^{2 *}$, Gita Susanti ${ }^{3}$ \\ ${ }^{1}$ Lecturer of the Department Administrative Science, Universitas Negeri Makassar, \\ ${ }^{2}$ Professor in the Department of Administrative Science, Hasanuddin University, \\ ${ }^{3}$ Department of Administrative Science, University of Hasanuddin
}

\begin{abstract}
The main objective of this study is to explain managing complexity through the resource-based view as a strategy for the implementation of food security policy. Because the study so far still focused on the form, type, and its dimensions. The study uses a qualitative design and case study strategy to explain the implementation of food security policy. Techniques of data collection used were observation, depth-interviews, and documentation. Based on the matching patterns and time series analysis, managing the complexity of resource sharing in the implementation of food security policy is not effective. This happens because the resources owned by them are not integrated through the governance network. Besides, the governance network organization does not have a clear vision, so they also behave in a changing manner and controlling their resources. This is shown by each government agency controlling the funds for this program and the extension workers do not have the necessary expertise in the food diversification, rice, and animal food programs. Therefore, resource sharing strategies that have value, rareness, imperfect imitability, and organization can achieve success ful implementation of this policy.
\end{abstract}

Keywords Managing complexity, resource-based strategy, implementation policy, and food security policy

\section{Introduction}

The complexity of public problems causes the government to have difficulty implementing various public policies because it has limited resources. These limitations include skills, finance, information, facilities, and infrastructure. This shows the government needs to involve the private and non-government sectors in the process of solving problems and meeting public needs. Such conditions no longer allow the government to become the main domain but require collaboration between stakeholders in this process [1], [2].

Collaboration among all stakeholders in the public service requires a synergy between actors, in this case, state, private and non-governmental organizations. The process of interaction in collaboration shows the interdependence between them and this shows the complexity in the process of public service delivery and policy. In addition, this complexity also occurs because those who have different backgrounds, interests, skills, and perspectives cause the delivery of public services and policy also vary [3],[4],[5],[6],[7]. This complexity can be demonstrated in food security policies because food security is a very urgent issue both nationally and internationally. In addition, it also includes stakeholders that are so varied that they have difficulty coping with this wicked problem. The increase in the world population affects the increase in food needs. Food crisis and hunger are a threat to the world. Based on data from FAO-UN 2009 showing the highes cases of food shortages and hunger since 1970, around 1.02 billion people experience food shortages and starvation. The worst conditions have occurred in Africa and South Asia. In fact, according to the UN Population (2000) predicts that in 2050, there will be an increase in the population of around 2.32 billion peoples who must be met their food needs under the pressure of an increasingly severe climate change threat [8].

Data from the Global Food Security Index (GFSI) shows that Indonesia's food security has increased from year to year, but this condition does not put Indonesia ahead of Southeast Asian countries such as Singapore, Thailand, Malaysia, and Vietnam. The score of GSFI in 2018 rose by 1.6 points to a level of 54.8 and placed Indonesia's position in the 5th place out of the Nine Countries of Southeast Asia. The food security index can be seen from the availability aspect of 58.2 (3rd rank). Then in terms of quality and safety, Indonesia only received a score of 34.5 (8th rank) while in terms of resilience and natural resources it received a score of 43.9. Singapore at the global level is superior with the highest food security index with a score of 85.9 , while Indonesia is in 65th position under Morocco and Ecuador. The data shows that Indonesia has not been able to compete with other countries to improve the Food Security Index. This shows that the complexity of the food security policy process. The government made various attempts as a form of governance network among them is the Food Security Council (DKP), which is set in Presidential Decree No. 132 of 2001. This policy attempted a gather all stakeholders to integrate resources through sharing

*Corresponding author: Alwi, Professor in the Department of Administrative Science, Hasanuddin University, Email: alwifisip@gmail.com 
resources in problem-solving and meeting food needs as a public domain. Therefore, the focus of this study is the resource-based strategy to overcome these strategic problems. This is done to overcome the theoretical gap, which has been concerned only with the form, type, and dimensions of the complexity [3],[7]

\section{Methods}

This study seeks to uncover and explain the managing complexity of the aspects of important resources sharing in governance networks. Resource sharing is a complex matter because the actors involved have different resources, interests, goals, and strategies in implementing this policy. The three cases of policy implementation are top-down approach policies, in which the central government designs its policies, then, its implementation is left to the local government, including provincial and regency/city governments. This kind of policy implemented in the separate simultaneously across Indonesia, so the performance of policies varies from one region to another, depending on the readiness and capability of local government agencies as an implementer of the policy. Food security policy is a complex policy because it involves many government agencies from the central government to the lowest government. In addition, many other actors outside the government are involved in the policy process, including the farmer groups as the target group.

1.Research Design and Strategy: The research design used in this study is qualitative research, which aims to uncover and explain managing complexity in the implementation of food security policy in Indonesia, includes food diversification, rice, and animal food programs. Then the research strategy used in this study is a case study with an explanatory type to explain phenomena in the implementation of food security policy based on the context.

2.Informants: The informants in this study are primary data sources that provide information about conditions and reality and are directly involved in policy implementation. The informants in this study are as follows: a) Chairman and members of the Farmer Group; b) Chairman and members of Gapoktan; c) District extension team; d) Region extension team; e) Head and staff of the Food Security Service, and f) Head and staff of the Department of Agriculture.

3.Data collection techniques: This study uses data collection techniques including observation, in-depth interviews, and documentation. Tangible objects are the focus of observations on the implementation of food security policy. The situation observed was Production, Distribution and Consumption activities. Then, in-depth interviews are addressed to all informants mentioned above. Subsequently, various documents were collected, such as regulations, laws, statistical data, reports on institutional activities related to the implementation of food security policy.

4.Processing and Data Analysis Techniques: The data processing technique used is data reduction through data categorization and classification. Then, the analysis techniques include pattern matching and time series techniques. Matching patterns based on theoretical patterns is a resource-based strategy that determines the success of policy implementation. In this study, these techniques are used together to complement each other [9].

The three stages of data analysis used in this study are: data reduction, data presentation and withdrawal and verification of conclusions [10]. Data are categorized and classified based on their similarities and differences after being collected through observation, in-depth interviews and documents.

\section{Results and Discussion}

There are three cases related to the implementation of food security policy, namely the implementation of food diversification policy, the implementation of rice policy and the implementation of animal food policy. The three cases are described based on the dimension of complexity, namely non-linear dynamics, selforganization, and co-evolution.

1. Case 1: Implementation of food diversification policy in Indonesia

The effort to accelerate food diversification is manifested in several aspects, namely consumption, development of food business, production, food independence, and self-sufficiency. The effort has not been effective as shown table 2 and 3 .

One of the complexities in governance networks can be seen from the process of interaction between actors. Each actor will appear with different knowledge and skills, he has information and perceptions of problems that tend to be different and the actors will tend to prioritize their respective interests. Each of the actors will try to maintain and try to achieve their own goals outside of the same goals in the organization.

Nonlinear dynamics interpreted as the difficulties to predict the future of the organization caused by the behavior of actors who often differ between one another. This causes the process interactions that are sometimes no longer unidirectional, erratic, and the performance of this policy be difficult to achieve. This can be shown in table 1 below.

Food diversification policy is not a new policy, long before this policy was launched. When viewed from the time of the realization of this policy, Indonesia should be able to achieve a high level of food diversification. In fact, from the date of the last three years, Indonesia's food security index tends to increase, but in reality, Indonesia's food security index is still in the low category and is unable to compete with other ASEAN countries' food security indices.

Table 1: follows the comparison of Indonesia's food security index with other ASEAN countries

\begin{tabular}{ccc}
\hline No & Country & Score $(\%)$ \\
\hline 1 & Indonesia & 54.8 \\
2 & Vietnamese & 56 \\
3 & Thailand & 58.9 \\
4 & Malaysia & 68.1 \\
5 & Singapore & 85.9 \\
\hline
\end{tabular}

Source: Databoks, 2018

Based on the table above, it can be seen that the Indonesian Food Security Index is at $54.8 \%$. Indonesia ranks fifth out of nine countries in the Southeast Asian region. Based on the affordability aspect, Indonesia's food security score of $55.2 \%$ and ranked 5 th in the Southeast Asia region. Then the score from the aspect of availability is $58.2 \%$ (ranked 3rd). Then from the quality and safety aspects, Indonesia only received a score of $34.5 \%$ (8th rank) while from the aspect of resilience and natural resources gained a score of $43.9 \%$ (9th rank). Food consumption quality indicators are shown by the Hope Food Pattern (PPH) score which is influenced by the diversity and balance of consumption between food groups. Table 2 below is targets and the realization of the desired food pattern in the last 4 years. Self - Organization: SelfOrganization focuses on how a system operates, develops and changes. This change includes the patterns of action and interaction of the actors, which in turn will form new structures or new organizations that are considered capable of achieving stability in the achievement of the interests of the actors. Government Regulation No. 68 of 2002 concerning Food Security states that food diversification is carried out to improve food security that takes into account local resources, institutions, and 
culture, by increasing food diversity, developing processing technologies and food products, and increasing public awareness to consume a variety of foods with the principle of balanced nutrition.

Table 2. Hope Food Pattern Score

\begin{tabular}{cccc}
\hline No & Year & Target (\%) & $\begin{array}{c}\text { Realization } \\
(\%)\end{array}$ \\
\hline 1 & 2015 & 84.1 & 85.2 \\
2 & 2016 & 86.0 & 86.2 \\
3 & 2017 & 88.4 & 90.4 \\
4 & 2018 & 90.5 & 90.7 \\
\hline \multicolumn{2}{l}{ Source: Ministry of Agriculture's Food Security Agency, 2018 }
\end{tabular}

Some of the programs that have been implemented are expected to support the food diversification policy. However, the problem of food insecurity remains a threat to Indonesia. The presence of the Indonesian Food Security Council is an effort to strengthen the achievement of the country's food security. This organization as a communication forum by the actors involved in implementing food diversification policy is an important part of food security.

Besides, several government programs in increasing food diversification are welfare equalization programs and handling poverty and food insecurity, which includes the Lestari food Home Area, Balanced and safe Diversity Food Consumption Movement (B2SA). Then the government also promoted the development of the local food industry, but its implementation has not been able to achieve the goal of diversifying food consumption. This can be seen from the level of rice consumption of Indonesian people which is still very high compared to other food commodities such as corn and tubers, as shown in Table 3 below. Based on the table above, from 2013 to 2017 the level of rice consumption continued to increase and was the highest compared to other food commodities. If compared with other countries such as South Korea number of rice consumption is only $40 \mathrm{~kg}$ per capita per year, Japan 50 kilograms per capita per year, Malaysia 80 kilograms per capita per year, and Thailand 70 kilogram per capita per year, then the levels of Indonesian rice consumption are still relatively high. This is in line with rice imports which are quite high even though Indonesia proclaimed itself as an agrarian country, as shown in Table 4 below.

Based on the table above, from 2013 to 2017 the level of rice consumption continued to increase and was the highest compared to other food commodities. If compared with other countries such as South Korea number of rice consumption is only $40 \mathrm{~kg}$ per capita per year, Japan 50 kilograms per capita per year, Malaysia 80 kilograms per capita per year, and Thailand 70 kilogram per capita per year, then the levels of Indonesian rice consumption are still relatively high. This is in line with rice imports which are quite high even though Indonesia proclaimed itself as an agrarian country, as shown in Table 4 below.

The rice import policy was carried out by the government because of the lack of inventory on the one hand and the high level of demand on the other. The main problem of food diversification is the imbalance between food consumption patterns and food production/availability in the community. In this case, not al regions can produce various types of food needed by following the ideal food consumption patterns.

Coevolution: The process of developing a network organization through interacting among actors and assuming that system changes can occur because there are changes in the interests of each actor. The implementation of the diversification policy on food includes many actors, one of which is the farmer group. This farmer group is the target group of this policy and it is an institution that grows and develops from, by, and for farmers to strengthen cooperation in fighting for farmers. The development of these institutions, such as farmer groups, an association of farmer groups (Gapoktan), and national commodity councils, can be shown in Table 5 below.

Table 3 Food Commodity Consumption Rate

\begin{tabular}{ccccccc}
\hline No & $\begin{array}{c}\text { Food } \\
\text { Commodities }\end{array}$ & $\begin{array}{c}2013 \\
\text { (Thousand Tons) }\end{array}$ & $\begin{array}{c}2014 \\
\text { (Thousand } \\
\text { Tons) }\end{array}$ & $\begin{array}{c}2015 \\
\text { (Thousand Tons) }\end{array}$ & $\begin{array}{c}\text { (Thousand Tons) } \\
\text { (Thousand Tons) }\end{array}$ \\
\hline 1 & Paddy & 68,000 & 70,000 & 75,000 & 79,000 & 80,000 \\
\hline 2 & Corn & 19,000 & 20,000 & 21,000 & 23,000 & 29,000 \\
3 & Cassava & 23,000 & 22,000 & 21,000 & 20,000 & 19,000 \\
4 & Sweet potato & 12,000 & 12,000 & 11,000 & 11,000 & 10,000 \\
\hline
\end{tabular}

Table 4: Number of Indonesian Rice Imports in the Last Three Years

\begin{tabular}{ll}
\hline Year & amount \\
\hline 2016 & 1.28 million tons \\
2017 & 3.05 million tons \\
2018 & 2.25 million tons \\
\hline
\end{tabular}

Source: Statistics Indonesia, 2018 
Table 5: Number of farmer groups in Indonesia

\begin{tabular}{ccc}
\hline Year & Farmers & Gapoktan \\
\hline 2016 & 527,310 & 62,061 \\
2017 & 561,791 & 63,120 \\
\hline Source: 2017 Agricultural Extension and Development Agency
\end{tabular}

The number of farmer groups that continues to grow indicates that community involvement in achieving food diversification policy is quite large. A team of extension workers to implement a food diversification policy fosters Farmer groups. An increase in the number of farmer groups is also followed by an increase in the number of extension workers. The number of extension agents per the year 2018 based on data from the Agricultural Human Resource Extension and Development Agency is 31,511 extension agents. In certain regions in Indonesia, 1 PPL (Field Extension Officer) accompanies 20-22 Farmer Groups originating from 1-2 villages, whereas ideally, 1 PPL accompanies 8-16 farmer groups. Overall, Indonesia still lacks 28,000 extension workers, with a total potential of 72,000 in the agricultural sector, while only 44,000 have become instructors. The implementation of food diversification must be done simultaneously; it can be started in rural areas by paying attention to the behavior of households including farm households as producers and consumers of food as well and by empowering local institutions as social capital in an effort to accelerate food diversification in rural areas.

Case 2: Implementation of the Rice policy in Indonesia: Rice is a staple food commodity and consumption levels are quite high when compared with countries in Asia. The average amount of Indonesian rice consumption is 36,413 million tons, Bangladesh is 21,490 million tons, Vietnam is 21,490 tons and Myanmar is 10,440 million tons per year (Data center and agriculture system, 2016).

Non-Linear dynamic: Complexity in organizational networks arises from the process of interaction between each of the actors involved. Actors involved in rice policy consist of government and non-government actors. Actor government, in this case, is the Ministry of Commerce, Ministry of Agriculture, State - owned enterprises, Public Cooperation Logistic Agency (BULOG), the House of Representatives and PT.PPI (Indonesian trading company). It also shows the many interests that play in the implementation of this policy. In addition, skills, knowledge, and perception of problems will also be different. This can be shown by the Ministry of Trade protecting farmers by refusing rice imports, in contrast to the Ministry of Agriculture protecting farmers by increasing rice production and PT PPI as a rice importing company in Indonesia. The differences of interest that exist in network organizations ultimately lead to a separate polemic in the implementation of this policy. Changes in behavior by each actor can occur depending on the interests of the actors. The behavior of actors in organizations that tend to experience changes is very dynamic so it is difficult to predict the performance of this policy.

There are several programs designed by the government to support the achievement of increasing rice production in Indonesia. The program is a rice self-sufficiency program, supply availability and price stabilization (KPSH) program. In the implementation of the KPSH, BULOG involves many parties with the Regional Government through the Department of Cooperatives, UMKM, and Trade or in charge at the Provincial / Regency / City level; Regional Inflation Control Team (TPID) of each region, and Regional and Owned Enterprises (BUMD) for Food and Markets. Self- Organization

Self- organization includes the development of this organization in the form of new structures or new organizations that show the increasingly complex issue. Indonesian Youth Farmers Movement
(GEMPITA) was born as a form of concern for the government, in this case, the Ministry of Agriculture to realize food selfsufficiency. Through this movement, it is expected that the young generation will not spend their time only on things that are not useful, but young people are invited to join together with the government to use abandoned land for agricultural development. The Agricultural Human Resources and Development Agency (BPPSDMP) together with the Youth Farmers Movement (GEMPITA) formed a Joint Business Group (KUB). To form assistance for farmers so that farmers are not left to walk on their own by building farmer corporations. The formation of youth organizations those are able to move youth to enter the world of agriculture.

The presence of the "Karang Taruna" as a youth organization is also part of the government's program to increase community participation in agricultural development. It is a place for youth development to develop economic, social and cultural activities. It intends to use all the potential that exists in society both human resources and natural resources itself. Based on the inter-census agriculture survey (SUTAS) BPS 2018, the number of young farmers that had aged about 25 years as many as 273839 people, while in 2013 only amounted to 187734 people.

"Pemuda Pancasila" as a youth organization is also involved in food security policy. Youth is the successor agency of the nation who can take an important role in strengthening food security. This organization is given the task to carry out the function of community empowerment through involving and giving authority to the community so that they can organize their lives more independently.

Coevolution: Indonesia is a country that includes a high level of rice consumption, which is 36.413 million tons per year with a population of 269.1 million. This is caused by the rise is the staple food of Indonesian citizens, so the government is very concerned with its supply. However, the government's systematic efforts in the form of a food security policy with various derivative policies have not yielded maximum results, as in Table 6 below.

Table 6: Comparison of Production and Consumption

\begin{tabular}{ccc}
\hline Year & Production & Consumption \\
\hline 2013 & 34 Million Tons & 39 Million Tons \\
2014 & 34.5 Million Tons & 34.5 Million \\
& & Tons \\
2015 & 43.9 Million Tons & 33.3 Million \\
& & Tons \\
\hline
\end{tabular}

Source: Ministry of Agriculture, Tempo Inti Media Harian, 2015.

Indonesia as an agrarian country is able to produce rice in large quantities. But almost every year, rice imports continue to be done to meet the needs of food stocks and supply parts of the deprived areas. In 2013, the consumption was very high reaching 39 million tons while Indonesia was only able to produce 34 million tons of rice. In 2015, rice production increased from the previous year which was 34.5 million tons to 43.9 million tons

Case 3: Implementation of Animal Food policy in Indonesia:

Non-linear Dynamic: The food problem is a very complex and multi-sector and multi-actor problem, especially in solving community nutrition problems. Consumption of food sourced from animal protein in sufficient quantities is needed to overcome various nutritional problems, including stunting. Regarding food supply for animal protein, the Ministry of Agriculture is expanding its self-sufficiency target from beef to livestock. However, these efforts have not effective. It can be shown that Indonesia only consumed 8 percent of animal food in 2018 and far below ASEAN 
countries, as shown in Table 7 below.

Table 7: Comparison of Indonesian Animal Food Consumption with Other Countries, 2018
Country
Consumption of Animal Protein

\begin{tabular}{cc}
\hline Indonesia & $8 \%$ \\
Malaysia & $28 \%$ \\
Philippines & $21 \%$ \\
Thailand & $20 \%$ \\
\hline
\end{tabular}

Community food consumption patterns differ between regions depending on the environment including natural resources, local culture, people's tastes, and income. Likewise, food consumption patterns also change from time to time which is affected by changes in income, changes in public awareness of the importance of food and nutrition, and lifestyle changes. Animal food consists of animal husbandry products in the form of meat, eggs, milk, and food from fisheries, which are divided into sea fish, shrimp, fresh fish, and salted fish. Food and Agriculture Organization (FAO) shows the level of consumption of animal protein in Indonesian society in 2017 still lags in developed countries even with some ASEAN countries. The cause of the problem is they have low purchasing power, besides meat is still a luxury food commodity with a relatively expensive price so that people on low incomes cannot afford to buy. The next obstacle is the growing number of Indonesia's population from year to year as well as increasing groups of people with higher income levels. This certainly causes the pattern of consumption of meat commodities also increase and the high demand for meat cannot be provided by the domestic market.

Table 8: The Level of Fish Consumption

\begin{tabular}{cccc}
\hline & 2016 & 2017 & 2018 \\
\hline Target $(\%)$ & 43.88 & 47.12 & 50.65 \\
Achievements & 43.94 & 47.34 & 50.69
\end{tabular}

$(\%)$

Source: Statistics Indonesia, 2018

Self- Organization: Efforts to maintain the sustainability of marine and fisheries resources in 2017 are carried out by encouraging the active involvement of the community, especially as a driving force for conservation. The Ministry of Marine and Fisheries initiated the formation of a conservation driving community group, abbreviated as KOMPAK. Also, the government assisted farmer groups as an effort to meet the demand for fish production, as illustrated in Table 8 below.

Some programs related to efforts to increase animal food consumption, such as the Movement to Promote Fish Eating (GEMAR IKAN), are an effort to increase fish consumption and to raise awareness of individuals and community groups about the importance of consuming fish. GEMAR IKAN as a national movement is carried out from the center to the local level. SelfSufficiency Program in meat, egg, and milk is an effort to deal with nutritional problems and continue to increase production and productivity. Likewise, this program seeks to increase the population and ensure the supply (production) of people for animal food to be Safe, Healthy, Undamaged and Halal (ASUH). The increase in animal food production is expected based on local resources. Another program related to this matter is The AISUMAKI (Indonesian Children love to eat fish). This program was initiated as an effort to strengthen Indonesia's food security that is expected to be able to increase the nutritional content for children. It does not only invite children to eat fish, but also become culinary entrepreneurs based on fishmeal.

Coevolution: The government continues to strive to increase animal food production as a source of protein as indicated by setting targets for beef self-sufficiency. The determination of beef self-sufficiency has been done for a long time, although with different names. Animal food consists of animal husbandry products in the form of meat, eggs, milk, and food from fisheries which are divided into sea fish, shrimp, fresh fish, and salted fish. This can be shown in Table 9 below. Based on table 9 above, the amount of animal food production tends to increase but not significantly. The production rate of 2 animal food commodities, namely eggs and milk, has increased in the last 4 years. However, the amount of beef production has fluctuated and tended to decline to reach 518,484 in 2016 and in 2019 it decreased again to 490,421. This is not in line with the level of animal food consumption which continues to increase. The level of consumption of animal food such as eggs, meat, and milk is based on data from the Ministry of Food Security Agency, 2019 as follows.

Table 10 above shows that the level of consumption of animal foods such as eggs, meat and milk continues to increase. However, the level of fulfillment of the national hope food pattern (PPH) of $12 \%$ has not been fulfilled. PPH for animal food in 2018 only reached $11.6 \%$.

Table 9: Animal Food Production

\begin{tabular}{ccccc}
\hline & \multicolumn{5}{c}{ 2016 } & 2017 & 2018 & 2019 \\
\hline Egg & $2,031,217$ & $2,089,997$ & $2,311,066$ & $2,371,457$ \\
Milk & 912,735 & 928,108 & 951,004 & 996,442 \\
Meat & 518,484 & 486,320 & 497,972 & 490,421 \\
\hline
\end{tabular}

Source: Directorate General of Animal Husbandry and Health, 2019

Table 10: Levels of Consumption of Animal Food

\begin{tabular}{ccccc}
\hline Animal Food & 2015 & 2016 & 2017 & 2018 \\
\hline Egg & 7,1 & 7,3 & 7,8 & 7,2 \\
Meat & 9,3 & 10,2 & 10,8 & 12,3 \\
Milk & 2,8 & 3,0 & 2,3 & 3,1 \\
\hline
\end{tabular}

Source: Ministry of Food Security Agency, 2019 
Various efforts have been made by the government to fulfill the need for animal food through increasing meat production, including encouraging the maintenance of cows from individuals to groups and providing group assistance by a team of experts Besides, it also develops crop-livestock integration patterns, such as cattle-oil palm integration. Then, it also carried out the development of pastureland, optimization of ex-mining land and grazing areas in eastern Indonesia, and facilitation of cattle business insurance (AUTS).

Based on table 11 above, food is a complex issue that is not possible to be handled by the government itself but needs to involve other parties to resolve it [1],[11],[12],[13]. This shows the need for synergy between these strategic actors to integrate their resources to achieve food security. Because the main purpose of the collaboration is due to the limited resources owned by an organization or stakeholders to achieve goals or gain competitive advantage [14]. These limitations then led to the emergence of efforts to integrate resources through resource sharing by the actors involved. Actors or stakeholders identified in this study can be in the form of organizations, groups, and individuals. Then, the resources can be in the form of skills, financial and information resources.

In solving problems and meeting the needs of public resources sharing by the actors involved becomes very important. This is because the public problem is a wicked problem, as food needs as the main staple food, while the government has limited resources for this. Government actors such as government agencies relating this issue each have resources but are not coordinated or integrated for the implementation of this policy. Then, the same thing is the organizations that exist outside the government relating to the implementation of this experience the same thing, so that the problem solving and meeting the food needs of citizens is not effective, especially in terms of meeting these needs through local food potential. The government relies more on rice imports even though this country is a very potential food producer.

This happens because the vision of services and meeting the needs of citizens is not clear so that both government agencies as government actors, private actors, and community-based organizations show changing or unclear behavior. Likewise, the resources they have are not integrated through resource sharing in the implementation of food security policies. In the perspective of strategic management, the vision and mission of the organization must be clear, because they determine the direction of the organization in the future [15],[16].

Managing the complexity of resource sharing for service delivery and public policy requires a resource-based strategy because managing them requires the capacity of public organization resources. In this case, the implementation of public service and policy becomes the main vision for public organizations, so that the ability of resources is a strategic factor of this organization. The vision of service delivery and public policy are not clear because resource sharing in the governance network of policy implementation does not happen. Resourcesbased strategy largely determines the success of policy implementation. An effective resource sharing process between each actor in a food security policy will determine the achievement of effective food needs for the community.

Resources are indeed a strategic factor in determining an organization's competitive advantage, but if an organization's vision is not clear then these resources will not support all strategic programs running effectively. This can be shown in this study that the food security policy is a governance network policy, but each actor in the government (local government agencies) each controls the resources they have in the implementation of this policy.

In addition, the food security policy as a governance network policy is not successful, because the resources owned by each actor especially actors outside the government are not integrated for the implementation of this policy. However, they have strategic resources that enable a network-based organization to achieve these policy objectives in a sustainable manner. The power sources can push this organization to sustained competitive advantages, such as value, rareness, imperfect imitability, and organization. The resources that satisfy such characteristics can achieve sustained competitive advantage [16], [17], [18].

Each local government agency has valuable resources, but there are local governmental agencies that have certain resources and are not owned by others but are important in implementing governance network policies. Then, in terms of quantity and quality of resources differ from one actor to another, so the integration of strategic resources through the governance network becomes important in the delivery of public service and policy.

Table 11: Managing Complexity Through Resource-Based Strategy for implementation of food security policy

\begin{tabular}{|c|c|c|c|}
\hline $\begin{array}{l}\text { Characteristics of } \\
\text { complexity }\end{array}$ & Case 1 & Case 2 & Case 3 \\
\hline \multirow[t]{5}{*}{ Non-linear Dynamic } & $\begin{array}{l}\text { Actors' behavior tends to } \\
\text { change }\end{array}$ & $\begin{array}{l}\text { Actors' behavior tends to } \\
\text { change }\end{array}$ & $\begin{array}{c}\text { Actors' behavior tends to change } \\
\text { Each government agency has a different }\end{array}$ \\
\hline & Each government agency & Each government agency & budget allocation \\
\hline & has a different budget & has a different budget & Required skills vary \\
\hline & allocation & allocation & \\
\hline & Required skills vary & Required skills vary & \\
\hline Self-organization & Less varied & Varies greatly & Less varied \\
\hline Coevolution & Low & High & Very low \\
\hline
\end{tabular}




\section{Conclusion}

Each actor involved in this program have strategic resources in solving problems and fulfill people's needs for foods. However, these resources were not integrated through resource sharing and the extension workers do not have the necessary expertise in the food diversification, rice, and animal food programs in the policy implementation. In addition, the managing strategic resources in the implementation of governance network policy do not have a clear vision, so the behavior of the actors are not clear, - changing in any occasion, resources controlled its own, including the actors in the government. Therefore, the actors need to agree and commit to establish a clear vision of network organization in the delivery of public service and policy. Then, resources that have values, rareness, imperfect imitability, and organization need to be integrated and managed effectively to meet the needs for food and the lives of the people will be sustainable.

\section{Acknowledgements}

We are very grateful to our intitutions.

\section{Ethical issue}

Authors are aware of, and comply with, best practice in publication ethics specifically with regard to authorship (avoidance of guest authorship), dual submission, manipulation of figures, competing interests and compliance with policies on research ethics. Authors adhere to publication requirements that submitted work is original and has not been published elsewhere in any language.

\section{Competing interests}

The authors declare that there is no conflict of interest that would prejudice the impartiality of this scientific work.

\section{Authors' contribution}

All authors of this study have a complete contribution for data collection, data analyses and manuscript writing.

\section{References}

[1] O'Leary R, Bingham, LB. The collaborative public manager: New ideas for the twenty-first century, Georgetown University Press, 2009

[2] Alwi, Kasmad, R. Local collaborative network: is it smart implementer of the cocoa business development policy in indonesia? International Journal Public Policy. 2018;14(5):374-390.

[3] Klijn EH, Koppenjan, J. The 11 Shift toward network governance. Theory and practice of public sector reform. 2016;(27), 158 .

[4] Brandsen T, Pestoff V. Co-production, the third sector and the delivery of public services: An introduction. Public management review. 2006;8(4):493-501.

[5] Thomson G, Frances J, Levacic R, Mitchell J. Markets, hierarchies and networks. The Coordination of social life, London: Sage, 1991.

[6] Marsh D, Rhodes RAW. Policy networks in British government. Clarendon Press, 1992.

[7] Considine, M. Governance and competition: The role of non-profit organizations in the delivery of public services. Australian journal of political science. 2003;38(1):63-77.

[8] United Nations. The United nations population fund (UNFPA) Annual Report, 2000.

[9] Yin, Robert K. Case study: design and method, Cet III, Translation of M. Djauzi Mudzakir, Jakarta: Raja Grafindo Persada, 2000.

[10] Miles MB, Huberman AM. Qualitative data analysis: An expanded sourcebook. Sage, 1994

[11] Bryson JM, Crosby BC, Stone, MM. Designing and implementing cross-sector collaborations: Needed and challenging. Public administration review. 2015;75(5):647-663.

[12] Agranoff, R. Collaborating to manage: A primer for the public sector. Georgetown University Press, 2012.

[13] Ansell C, Gash A. Collaborative governance in theory and practice. Journal of public administration research and theory. 2008;18(4):543-571.

[14] Barney JB, Clark DN. Resource-based theory: Creating and sustaining competitive advantage. Oxford University Press on Demand, 2007.

[15] Sharhan AAM, Bora C. Effect of audit committee characteristics on audit quality: A critical literature review. Journal of Advanced Research in Economics and Administrative Sciences. 2020;1(1):1-12.

[16] Wernerfelt BA. Resource-based view of the firm. Strategic Management Journal, 1984;5(2):171-180.

[17] Insani N. Apparatus Professionalism and Public Service Ethics. Journal La Sociale, 2020;1(1): 25-28.

Sharhan AA, Bora C. Effect of Audit Committee characteristics on Audit Quality: A Critical Literature Review. Journal of Advanced Research in Economics and Administrative Sciences, 2020;1(1):1-12. 